\title{
Socio-economic determinants of the awareness and adoption of citrus production practices in Pakistan
}

\author{
Determinantes socioeconômicos da conscientização e adoção de práticas de \\ produção de citros no Paquistão
}

\begin{abstract}
Saleem Ashraf ${ }^{1}$ Ghazanfar Ali Khan ${ }^{\text {II }}$ Shoukat Ali ${ }^{\text {II }}$ Muhammad Iftikhar ${ }^{\text {II }}$
\end{abstract}
\section{ABSTRACT}

Citrus is the leading fruit of Pakistan and famous worldwide especially kinnow cultivar because of its pleasant taste and remarkable quality. The yield of citrus per hectare in Pakistan is almost half of potential due to non-adoption of recommended horticultural practices by citrus growers. Adopting a decision regarding the improvement of practices is usually influenced by various factors including farmers' socio-economic attributes. In order to determine the relationship between socio-economic aspects and the awareness and adoption of recommended citrus production practices the present study was carried out in Sargodha district from central Punjab, Pakistan. The Study was based upon cross sectional survey research design due to availability of sampling frame, probability (random sampling) was applied for sample selection. Through random sampling, 120 citrus growers were selected as sample. Structured questionnaire administered through interview was used as a research instrument. Analysis of the data collected from the targeted citrus growers revealed a highly significant influence of education on awareness and adoption. Moreover, significant association was found between citrus cultivation area and awareness and adoption of improved practices. Age also showed significant association with awareness and adoption. Moreover, dominancy of middle aged farmers and illiteracyin the study area strongly point the need of provision of formal and non-formal education and training program for farmers. Young generation needs to be focused and reorientation of youth clubs may help in better way to gain the utmost outcome.

Key words: awareness, adoption, citrus, horticultural, agri. extension.

RESUMO

Citrus é fruto líder do Paquistão e famoso no mundo inteiro, especialmente Kinnow, cultivado por causa do sabor agradável e de qualidade notável. Por hectare, o rendimento de citrus no Paquistão é quase metade do potencial, devido à não-adoção de práticas de horticultura recomendadas por citricultores. A adoção da decisão sobre práticas melhoradas geralmente é influenciada por vários fatores, incluindo atributos socioeconomicos dos agricultores. A fim de determinar a relação entre os aspectos socioeconômicos e a consciência e adoção de práticas de produção de citros recomendadas presentes, este estudo foi realizado no distrito de Sargodha do centro de Punjab, Paquistão. O estudo foi baseado em projeto de pesquisa do estudo transversal e, devido à disponibilidade de amostragem, amostragem quadro probabilidade (amostragem aleatória) foi aplicada para a seleção da amostra. Por meio de amostragem aleatória, 120 citricultores foram selecionados como amostra. Questionário estruturado, aplicado por meio de entrevista, foi utilizado como um instrumento de pesquisa. A análise dos dados coletados dos citricultores direcionados revelou uma influência altamente significativa da educação sobre a conscientização $e$ adoção. Além disso, foi encontrada associação significativa entre a área de cultivo de citrinos e conscientização e adoção de práticas melhoradas. A idade dos produtores também mostrou associação significativa com a conscientização e adoção. Além disso, a dominância dos agricultores de meia idade e a falta de conhecimento na área de estudo apontam fortemente para a necessidade de oferta de educação formal e não-formal e de formação para os agricultores. Necessidades de geração de jovens a ser focado e reorientação dos clubes de jovens pode contribuir para melhor maneira de ganhar o máximo resultado.

Palavra-chave: conscientização, adoção, citrus, horticultura, extensão agrária.

\section{INTRODUCTION}

Citrus is the leading fruit of Pakistan and the greatest producer of Kinnow in the world with annual output of 2150.0 thousand tones (GOVT. OF PAKISTAN, 2011). It grows mostly in areas of central

\footnotetext{
In-Service Agricultural Training Institute Sargodha, Pakistan. E-mail: saleem1828@gmail.com. Corresponding author.

IIInstitute of Agricultural Extension \& Rural Development, University of Agriculture Faisalabad, Pakistan.
} 
Punjab such as Sargodha, Jhang and Toba Tek Singh. In addition, Sargodha is the major citrus producer in the entire country. Citrus is also an important source of income to the resident of citrus producing areas. Its exports contribute significantly in the economy of country exporting about 533 thousand tones of citrus in 2011 (GOVT. OF PAKISTAN, 2011). Despite of this importance, the average production of citrus is almost half of the potential and several factors are responsible for this low production. The most prominent problem identified is the non adoption of the latest technologies. The importance of technology to agricultural development especially in developing countries is widely recognized. In developing countries where a greater proportion of the population resides in rural areas, agricultural technology could also provide a potential means to increase production and subsequently raising incomes of farmers as well as their standard of living (ANI et al., 2004). Socio economic aspects also have an impact on awareness and adoption of technology and success of technology depends on its dissemination among the potential users, which ultimately is measured by the level of adoption of that technology (REDDY \& REDDY, 2002). Traditional method of farming predominates in most localities, resulting from a perennial low input and low output relationship, especially communities which has less education. NZOMOI (2007) reported that the variables that influence technology adoption are level of education, local technology financial constraints, land tenure system and land size or farm size. Information and communication technologies can bridge the information gap through dissemination of improved techniques but problems of farmers as less education, computer illiteracy, small lands, costly ICTs infrastructure, and social norms make all the efforts in vain (SAGHIR et al., 2009). The above mentioned facts reveal the relationship that exists between socio-economic aspects and the awareness and adoption of technology. Moreover, notable improvements can take place regarding agriculture, if the available technologies are accepted and adopted by the farmers. Therefore, the present study was focused to determine the relationship between socioeconomic characteristics of citrus growers and their awareness and adoption of recommendations in central Punjab Pakistan. The basic objective of this study was to establish the relationship between the socio-economic characteristics of respondents and awareness and adoption of technologies.
Conceptual framework

The conceptual framework was derived on the basis of two researchers AYOOLA (2012) and ROGERS (1992) who provided the basis by revealing that diffusion of an innovation occurs through a five step process: awareness (knowledge), interest (persuasion), evaluation (decision), trial (implementation) and adoption (confirmation); which was defined as follows:

1) Awareness stage is the stage in which the individual is first exposed to an innovation but there is a lack of information about the innovation.

2) Interest is the stage $t$ in which the individual is interested in the innovation and actively seeks information about the innovation.

3) Evaluation sis the stage in which the individual takes the concept of the innovation and weighs the advantages and disadvantages of using the innovation and decides whether to adopt or reject the innovation. ROGERS (1992) reported that is the most difficult stage to acquire empirical evidence.

4) Trial the stagein which the individual employs the innovation to a varying degree depending on the situation. During this stage, the individual determines the usefulness of the innovation and may search for further information about it.

5) Adoption e is the stage that the individual finalizes their decision to continue using the innovation and may use the innovation to its fullest potential.

6) The rate of adoption is also defined as the relative speed in which members of a society adopt an innovation; whereby, an individual who first adopts an innovation (early adopter) requires a shorter adoption period than late adopters.

Furthermore, the process adopted is influenced by the socio economic aspects such as age, education, land holding size etc. So, the present study was carried out focusing on analyzing the impacts of socio-economic attributes on awareness and the adoption of improved production practices.

\section{METHODOLOGY}

Citrus is produced in four provinces of Pakistan but the Punjab holds $95 \%$ of the total production (SHARIF, 2005; PBIT, 2012). Sargodha is the major city of central Punjab and mainly comprises flat, fertile plains, which are the ideal conditions for cultivation of the land. Climate varies from extreme heat and cold with maximum temperature $50^{\circ} \mathrm{C}(122 \mathrm{~F})$ in the summer whiles the minimum temperature as low as freezing point in the winter. Therefore, it is the Pakistan`s best and 
leading citrus producing area (SARWAR et al., 2012). Therefore, this study was carried out in tehsil Kot Momin of district Sargodha where the major occupation of people is also citrus farming.

Sampling procedure and sample size

The present study was based upon cross sectional survey research design. Entire population was homogeneous and researchers were having sampling frame, providing sound basis for probability sampling studied area consisted of total 24 union councils. being, 22 rural 2 urban. Out of 22 rural union councils, 5 were selected randomly. From each selected union council, 2 villages were selected at random. From each of the selected village, 12 growers were selected by simple random sampling technique, thereby making a sample size of 120 respondents.

\section{Data collection}

A structured questionnaire was used as research instrument. However, this structured questionnaire was administered through interview. Instrument was pre tested for the validity and reliability. Face validity of instrument was also checked through experts.

Data analysis

Data were analyzed through SPSS and inferential statistics was applied to identify the relationship. Chi Square test and regression analysis was applied. Before chi square test application total recommendations regarding awareness \& adoption were computed through SPSS.

Computation of awareness and adoption levels

Awareness: First of all, total recommendations were counted in order to ascertain farmers' level of awareness about the citrus recommendations included in the study. A score of one was given if the grower was aware of and two to those to whom he was unaware. An awareness index was then developed by adding the number of recommendations with which the respondent was aware of. The maximum and minimum scores were 55 and 47. Respondents were then divided into three awareness categories i.e., low (47-49), moderate (50-52), and high (5355) based on awareness score.

Adoption: First of all, total number of recommendations was counted in order to determine farmers' level of adoption about the citrus production recommendations included in the study. Score of one was given to each adopted recommendation and 2 to non-adopted recommendation. An adoption index was then developed by adding the adopted recommendations. The maximum and minimum scores obtained were 77 and 43 respectively. Respondents were then divided into three categories i.e. low (43-53), moderate (54-65), and high (66-77) on the basis of adoption score.

\section{RESULTS AND DISCUSSION}

Socio-economic attributes

Data revealed that most of the respondents (48.4\%) belonged to middle aged ( $>35-50)$ category followed by the $38.3 \%$ and $13.3 \%$ respondents belonging to young and old aged category. Almost one third $(29.2 \%)$ of the respondents were illiterate, while $70.8 \%$ of respondents were having formal education of different levels. Regarding the educational level, maximum percentage (30) of respondents found had primary to middle level education while $12.5 \%$ respondents were found with the maximum educational level. Vast majority of respondents $(81.6 \%)$ was owner of their lands. Negligible percentage (3.33) of respondents was tenant followed by the $15 \%$ owner cum tenants. Most of the respondents $(39.1 \%)$ were small landholders (up to 5 acres) while only $28.3 \%$ of the respondents had above 10 acres of land. Almost half (45.9\%) respondents were having cultivation of citrus on up to 5 acres land. Just $17.5 \%$ respondents were found with above 10 acres cultivation of citrus.

Relationship of socio-economic attributes with awareness

The data presented in tables 1-4 indicate that there existed positive relationship between age and awareness of the respondents. Findings infer that as the age of the farmers' increase, maturity increase which may boosts the interest to acquire new information. SIDDIQUI et al. (2006) were of the view that age and awareness of farmers have a negative association. This author said that with the age increasing, interest to seek new information goes down.

Data further depicted have a highly significant association between education and awareness. As the educational level increase, the interest to gather information increases. It is also said that educated persons become able to take risks in farming by adopting innovative techniques and practices. However, educational level of growers in the studied area was 
Table 1 - Relationship between age of the respondents and awareness and adoption.

\begin{tabular}{|c|c|c|c|c|c|c|}
\hline \multirow{3}{*}{ Age } & \multicolumn{3}{|c|}{ 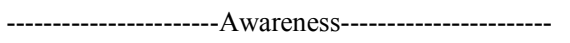 } & \multicolumn{3}{|c|}{ 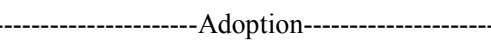 } \\
\hline & Low & Medium & High & Low & Medium & High \\
\hline & \multicolumn{3}{|c|}{-----------------------Percentages----------------------- } & \multicolumn{3}{|c|}{----------------------Percentages-------------------' } \\
\hline Young (Up to 25 years) & 23.3 & 17.5 & 0.83 & 4.16 & 11.66 & 74.16 \\
\hline Middle (26-50) & 20.0 & 24.16 & 0.83 & 0.83 & 3 & 6.66 \\
\hline Old (Above 50) & 6.66 & 6.66 & 0 & 0 & 0 & 0 \\
\hline
\end{tabular}

$\mathrm{X}^{2}=1.751$

$\mathrm{X}^{2}=1.732$

substantially good, documenting $29 \%$ of the illiterate farmers. This inadequate educational level implied might cause lower productivity of citrus. Findings of SIDDIQUI et al. (2006) endorsed the significant association of education and awareness level. SALEHIN at al. (2009) had also documented significant relationship between education and awareness because education develops sense among farmers to adopt the cost effective technologies.

Land is anticipated atural assets and pride of farmers in society. Farmers' response showed non-significant association with land holding size. However, it is fortunate to say that with large land holding size farmers may gain extended interest in seeking new information. Land under citrus cultivation was also proven to have non-significant association.

Relationship of socio-economic attributes with adoption

The data presented in tables 1-4 showed a non-significant relationship between adoption and socio-economic attributes like age but highly significant association between education and adoption of improved citrus production practices. Findings infer that education enhances adaptive capacity of the farmers enabling them to manage production function and cost of production. HASSAN et al. (2002) and SIDDIQUI et al. (2006) had also showed significant association between education and adoption of production practices. Moreover, data reflect that illiteracy showed lesser percentage (3.33) of adoption at low level. This percentage significantly increased for adoption by the respondents having middle $(75.83 \%)$. This indicates that educated farmers were more adopters of the recommendations as comparative to illiterate of having ordinary education. Similar findings were also reported by NLERUM (2006). SALEHIN et al. (2009) also reported significant relationship between education and adoption. Furthermore, small land owners had maximum adoption level as indicated by highest percentage $(77.5 \%)$. Growers having cultivation of citrus on 5-10 acres shoed maximum adoption as the percentage was 75.83. Further data further indicated that there existed non-significant relationship of age and size of landholding with adoption of recommended horticultural practices regarding citrus.

Table 2 - Relationship between Education of the respondents, awareness and adoption.

\begin{tabular}{|c|c|c|c|c|c|c|}
\hline \multirow{3}{*}{ Education } & \multicolumn{3}{|c|}{------------------------Awareness------------------------ } & \multicolumn{3}{|c|}{-Adoption----------------------- } \\
\hline & Low & Medium & High & Low & Medium & High \\
\hline & \multicolumn{6}{|c|}{ 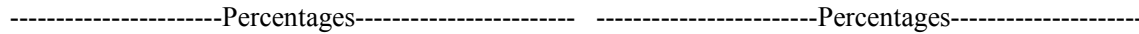 } \\
\hline Illiterate & 10.0 & 14.16 & 0 & 0 & 3.33 & 5.0 \\
\hline Up to middle & 15.0 & 8.33 & 0 & 5.0 & 10.83 & 75.83 \\
\hline Above matric & 11.66 & 10.0 & 3.33 & - & - & - \\
\hline
\end{tabular}

$\mathrm{X}^{2}=16.838^{* *}$

$\mathrm{X}^{2}=6.270^{*}$

Ciência Rural, v.45, n.9, set, 2015. 
Table 3 - Relationship between land holding size of the respondents, awareness and adoption.

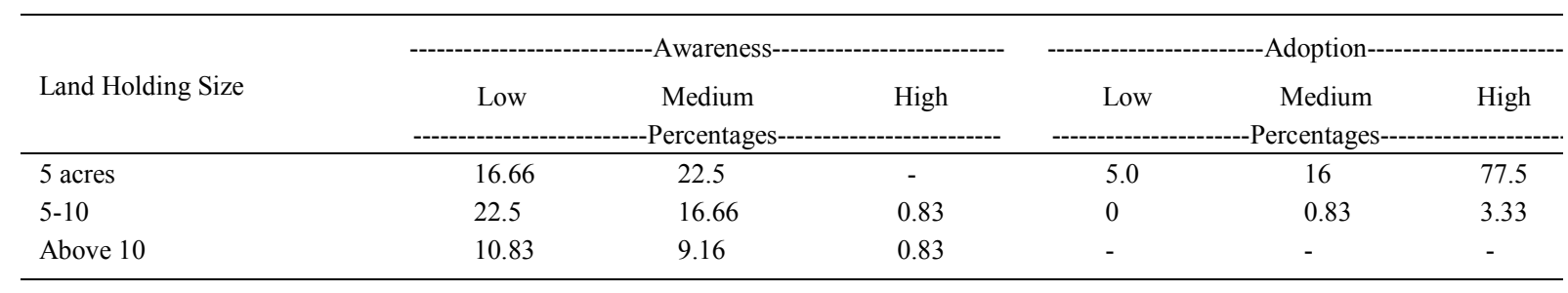

$\mathrm{X}^{2}=3.912$

$\mathrm{X}^{2}=0.387$

Regression analysis

According to the data depicted in table $5 \beta$ values for age had a negative coefficient thus negative relationship. However the education and landholding size had positive relationship. The negative and positive $\beta$ values indicated the direction of relationship between predictors and outcome.

Regression analysis indicated that such factors such as age had negative relationship with the adoption of improved citrus production practices. In addition significantly positive relation of factors such as education was found which implies that the education will increase the adoption and the asame case can be observed regarding holding a large landholding size. Relationship of adoption with land holding size was also positive.

\section{CONCLUSIONS}

The passage of time promotes technologies for enhanced productivity. However, adoption process is slow and growers' interest varies according to the feasibilities of technology. Awareness and adoption depends upon several elements like socio-economic attributes of the growers including their age, education, land holding size, income sources and land on which particular crop is sown. Generally, socioeconomic attributes build farmers adaptive capacity. Farmers with strong adaptive capacity are anticipated as innovators and early adopters. The present study also discussed and concluded that socio-economic attributes holds strong bonding with awareness and adoption of production practices. In the present study, education showed highly significant association with awareness and adoption. Age also showed significant association with awareness and adoption of practices. Based on findings it is recommended that formal and non-formal education should be promoted among the farmers by the training institutes. Extension Field Staff can also play role in provision of adult education for farmers emphasizing on farmers field schools. Utilization of electronic media and social media can support the education in proper way. Old age farmer may lose their momentum. In this context, young generation should be focused and kept on priority by providing them education and training facilities. Reorientation of youth clubs on farm level can be viable solution.

Table 4 - Relationship between size of citrus orchard of the respondents awareness and adoption.

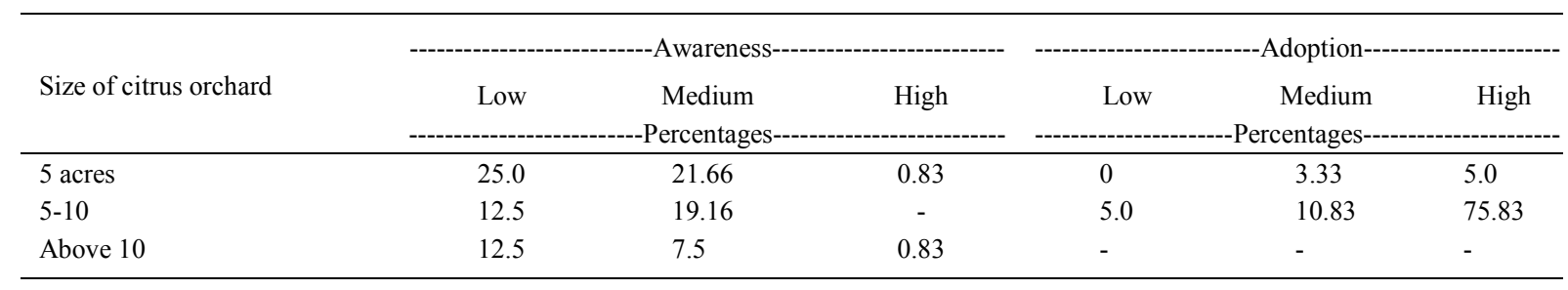

$\mathrm{X}^{2}=4.917$

$\mathrm{X}^{2}=6.270^{*}$

Ciência Rural, v.45, n.9, set, 2015. 
Table 5 - Regression analysis.

\begin{tabular}{|c|c|c|c|c|c|c|c|c|c|c|c|c|c|}
\hline \multirow{2}{*}{$\begin{array}{l}\text { Model } \\
1\end{array}$} & & \multicolumn{2}{|c|}{$\begin{array}{l}\text { Unstandardized } \\
\text { coefficients }\end{array}$} & \multirow{2}{*}{$\begin{array}{c}\text { Standardized } \\
\text { coefficients } \\
\text { Beta }\end{array}$} & \multirow{2}{*}{$\mathrm{t}$} & \multirow{2}{*}{ Sig. } & \multicolumn{2}{|c|}{$\begin{array}{l}95 \% \text { Confidence } \\
\text { interval for } \beta\end{array}$} & \multicolumn{3}{|c|}{-------Correlations------- } & \multicolumn{2}{|c|}{$\begin{array}{l}\text { Collinearity } \\
\text { Statistics }\end{array}$} \\
\hline & & $\beta$ & Std. error & & & & $\begin{array}{l}\text { Lower } \\
\text { Bound }\end{array}$ & $\begin{array}{l}\text { Upper } \\
\text { Bound }\end{array}$ & $\begin{array}{l}\text { Zero } \\
\text { Order }\end{array}$ & Partial & Part & Tolerance & VIF \\
\hline & (Constant) & 2.633 & .459 & & 5.735 & .000 & 1.724 & 3.542 & & & & & \\
\hline & Age & -.194 & .163 & -.109 & -1.187 & .238 & -.518 & .130 & -.110 & -.110 & -.109 & .995 & 1.005 \\
\hline & Education & .172 & .177 & .090 & .972 & .033 & -.179 & .524 & .090 & .090 & .089 & .996 & 1.004 \\
\hline & Landholding & .008 & .246 & .003 & .034 & .973 & -.479 & .495 & .016 & .003 & .003 & .991 & 1.009 \\
\hline
\end{tabular}

\section{REFERENCES}

ANI, A.O. et al. Relationship between Socio-Economic Characteristics of Rural Women Farmers and Their Adoption of Farm Technologies in Southern Ebonyi State, Nigeria. International Journal of Agriculture and Biology, v.6, n.5, p802-805, 2002.

AYOOLA,J.B. Socio-economic determinants of the adoption of yam minisett technology in the Middle Belt Region of Nigeria. Journal of Agricultural Science, v.4, n.6, p.215-222, 2009.

GOVT. OF PAKISTAN. Pakistan statistical year book. Islamabad: Federal bureau of statistics, Statistics division, 2011.

HASSAN, M.Z.Y. et al. Effect of socio-economic aspects of mango growers on the adoption of recommended horticultural practices. Pakistan Journal of Agricultural Sciences, v.39, n.1, p. 20-21, 2002.

NLERUM, F.E. Socio-economic characteristics as correlates of adoption among Yam Farmers in Rural Ikwerre Areas of Rivers State, Nigeria. Global Approaches to Extension Practice, v.2, n.2, p.74-80, 2006.

NZOMOI, J.N. et al. Determinants of technology adoption in the production of horticultural export produce in Kenya. African Journal of Business Management, v.1, n.5, p.129-135, 2007.

PBIT. Punjab board of investment and trade. Punjab Investment Review, n.7, p1-4, 2012.
REDDY, G.R.; REDDY, S.J. Extent of adoption of paddy technologies by the different selected enterprise farmers. Journal of Research ANGRAU, v.30, n.2, p.74-88, 2002.

ROGERS, E.M. Diffusion of innovations. ed. New York: The Free, 1992. A Division of Simon \& Schuster Inc.1230. Avenue of the Americas, New York, NY.

SAGHIR, A. et al. Gender and information and communication technologies (ICTS). Journal of Animal and Plant Sciences, v.19, n.2, p.94-97, 2009.

SALEHIN, M.M. et al. Socioeconomic changes of farmers due to adoption of rice production technologies in selected areas of Sherpur district. Journal Bangladesh Agriculture University, v.7, n.2, p.335-341, 2009.

SARWAR. G. et al. Quality of inputs and technical efficiency nexus of citrus farmers in district Sargodha. International Journal Academic Research in Business and Social Sciences, v. 2, n. 1, p. $315-323,2012$.

SHARIF, M. et al. Citrus marketing in Punjab: constraints and potential for improvement. Pakistan Development Review, v.44, n.4, p.673-694, 2005.

SIDDIQUI, B.N. et al. Effect of socio-economic aspects on the awareness and adoption of recommended horticultural practices by Apple growers in Baluchistan, Pakistan. Pakistan Journal of Agricultural Sciences, v.43, n.1-2, p.73-76, 2006. 